\title{
PENSION POLICY CHALLENGES AND COMMUNICATION POSSIBILITIES - EMPIRICAL STUDY OF HUNGARIAN UNIVERSITY STUDENTS NYUGDÍJPOLITIKAI KIHÍVÁSOK ÉS KOMMUNIKÁCIÓS LEHETŐSÉGEK - MAGYAR EGYETEMI HALLGATÓK EMPÍRIKUS VIZSGÁLATA
}

\author{
Nándor Komáromi PhD', Nikolett Mihály $\mathbf{P h D}^{2}$ \\ ${ }^{1}$ Assistant Professor, ${ }^{2}$ Associate Professor \\ ${ }^{1,2}$ Szent István University, Faculty of Economics and Social Sciences \\ E-mail: ${ }^{1}$ Komaromi. Nandor@gtk.szie.hu, ${ }^{2}$ Mihaly.Nikolett@gtk.szie.hu
}

\begin{abstract}
The most important question of our study is to find out what pension policy procedures are necessary to respond effectively to the challenges of an aging population as well as changes in the composition of employees. We examine the characteristics and communication practices of pension reforms in international literature (secondary research). The main issue of our paper is how pension policy can effectively respond to changes of demographical transition. It is very important to examine whether changes to pension policy are adapted to groups in society and if so, which kind of communication should be used. We measured university students regarding of age and gender specialties in financial attitudes and preparing for retirement. We tried to prepare persuasion strategies that reinforce the retirement saving motivation. Our research is therefore a search for a major project.
\end{abstract}

\section{Összefoglalás}

Tanulmányunk legfontosabb kérdése, hogy milyen nyugdíjpolitikai eljárásokkal lehet hatékonyan reagálni egy elöregedő társadalom kihívásaira, a munkavállalók összetételének változásaira. Munkánk megalapozásaként nemzetközi nyugdíjreformok jellegzetességeit és gyakorlatait gyüjtöttük össze irodalmi elemzés és összehasonlító munka segítségével. Kiemelt hangsúlyt kapott annak vizsgálata, hogy a lehetséges nyugdíjpolitikai szabályozásoknak milyen társadalmi beágyazhatósága van, illetve az esetleges változásokat hogyan érdemes kommunikálni. Egyetemi hallgatók mintáján vizsgáltuk, hogy a pénzügyi attitüdrendszer és a nyugdíjas időszakra való felkészülés milyen jellemző életkorbeli és nemek közötti különbsgégeket mutat. Ezzel próbáltuk azokat a megygyőzési stratégiákat elökészíteni, melyek a nyugdíj előtakarékossági hajlandóságot erősítik. Kutatásunk tehát egy nagyobb projekt előkutatásának minősül.

Keywords: management, pension policy, innovation

JEL classification: E02, H55, H75

LCC: JN 1601-2192; H1-99

\section{Introduction}

The basic question of the economic, social, political (and other) stability of a country is how it works and how the generally introduced and accepted pension system (if any) is regulated. The fact what the breakdown of state-owned, employment-based (corporate) and individual savings looks like is primarily a macroeconomic, business mathematical issue. However, it is also evident that the traditions of regulations and the impacts of the previous successful/unsuccessful reforms will certainly effect on social acceptance and the reaction of different social groups. 
Before shaping pension systems and pension reforms it is essential that some insights should be gained about the possible acceptance of the system. The attitudes and competencies of the different social strata and groups related to pension must be revealed.

As the general feature is the changing demographic structure of societies, i.e. typically ageing, that is why the issue of altering the pension system is undoubtedly important and timely. First, we examine how the possible pension policy regulations are socially accepted and what communication tools we can use for these changes. Our research serves as a pilot to a greater scale future project.

The methodology of the research follows the traditional structure. Secondary research is carried out as the first step. The international and national literature on the topic is reviewed, synthesised, compared and evaluated. As the second step, preliminary qualitative research is carried out on a selected target group, who are, in this case, the students of the Faculty of Economics and Social Sciences at Szent István University. The method was personal interview. When choosing the target group not only accessibility was important but also other facts, i.e. we were very curious who the persons that are going to be pensioners in the far future are like, how knowledgeable they are in the topic, what expectations they have, to what extent they are aware of their behaviour and what forms of communication they accept, were considered. As the third step quantitative research (questionnaire) was planned. The target audience here was also the students of SZIU Faculty of Economics and Social Sciences but on a greater sample and also the results were statistically evaluated.

The previously mentioned greater-scope project for the future means the extension of the current one regarding both demographic characteristics and sample size. We hope that we can ensure the necessary sources by making use of the experience gained.

\section{Literature review - pension systems, communication and financial consciousness}

Literature review right at the beginning resulted in two surprising facts.

- The literature on the topic is extremely rich regarding both international and Hungarian sources. The World Bank, OECD, IMF, the European Union, the statistical offices and other organisations of the countries and, of course, universities and research institutes among others, deal with the operation and reforms of pension systems. On a national level the Central Statistical Office (KSH), the National Bank of Hungary (MNB), business and other research institutes, universities and products of the business press could be mentioned but here the list could also be longer. (Of course, we think of scientific and reliable sources and not the short and sometimes 'sensational' articles of everyday papers.)

- The literature on the topic has an almost exclusively economic, business mathematical and statistical nature with some exceptions like the paper of Atkinson et al. (2012) which is an OECD publication summarising principles and case studies about the communication of the pension system reforms.

This paper presents the pension system of Germany, Poland, Sweden and Japan in addition to Hungary. Beyond the limitations in length, our choice is also justified by the facts that the German, Polish and Swedish example is also from the EU; we have a lot in common with Poland; Sweden is often set as an example; the economy of Germany is decisive within the EU and also the Japanese example was carried out under basically different historical, cultural and economic conditions. Table 1 . shows a short comparison of the pension systems according some indicators. 
Table 1. The key indicators of the pension systems

\begin{tabular}{|l|l|l|l|l|l|}
\hline Indicator & Germany & \multicolumn{1}{|c|}{ Poland } & Sweden & Japan & Hungary \\
\hline $\begin{array}{l}\text { pension expenditures } \\
\text { as of \% of GDP }\end{array}$ & $10.6 \%$ & $\begin{array}{l}10.8 \% \\
\text { (max.) }\end{array}$ & $\begin{array}{l}7.4 \% \\
(\mathrm{~min} .)\end{array}$ & $10.2 \%$ & $10.0 \%$ \\
\hline $\begin{array}{l}\text { life expectancy at } \\
\text { birth }\end{array}$ & $\begin{array}{l}80.7 \text { years } \\
(\mathrm{max} .)\end{array}$ & 76.3 years & 81.7 years & 83.5 years & $\begin{array}{l}74.5 \text { years } \\
(\mathrm{min} .)\end{array}$ \\
\hline $\begin{array}{l}\text { percentage of the } \\
\text { above 65 }\end{array}$ & $21.4 \%$ & $\begin{array}{l}15.3 \% \\
(\mathrm{~min} .)\end{array}$ & $20.0 \%$ & $\begin{array}{l}26.4 \% \\
\text { (max.) }\end{array}$ & $17.6 \%$ \\
\hline
\end{tabular}

Source: OECD (2015)

As we can see the Sweden system is the most economical, and the biggest reform challenge is in Japan as there is the highest percentage of the above 65. Life expectancy at birth is lowest in Hungary, which means that we have tasks to improve the health care system. In the following parts, we show the different system in details.

\section{Pension system in Germany}

In Germany the compulsory state pension system has one pillar and is pay-as-you-go based on salaries. If it is not sufficient for supporting the old, further allowances based on entitlement are distributed from the social support system.

Table 2. The key indicators of the pension system in Germany

\begin{tabular}{|l|l|}
\hline Indicator & Value \\
\hline average salary & 45952 EUR \\
\hline pension expenditures as of \% of GDP & $10.6 \%$ \\
\hline life expectancy at birth & 80.7 years \\
\hline life expectancy above 65 & 19.4 years \\
\hline percentage of the above-65 & $21.4 \%$ \\
\hline
\end{tabular}

Source: OECD (2015)

Conditions of entitlement to pensions at present include 65 years and 2 months. Pension can be received after paying in at least two years' contributions. In the forthcoming two decades the age limit is expected to continuously be growing to above 67 .

The salary-based pension system is based on points. The extent of the contribution depends on how much the person earns (and points are calculated on the basis of this). When reaching the retirement age points are calculated and added for every year going back to the past. Then the accumulated points are multiplied in line with the current pension point value (in 2014 it was 337.68 EUR). The pension point value is applied for those retiring now and also for those who have already retired. The pension point value is set to the current GDP. Moreover, the 'contribution factor' also takes into account the changes in the amount of contributions to state pension scheme and the composition of voluntary pension. The increase in the amount of contribution will reduce adjustment to the pension point value. The 'sustainability factor' measures the changes in the single contributions as of single pensioners, which is also in connection with the possible changes in the point values.

These two factors of the indexing formula can modify the amount of adjustment, which is expected to result in $14 \%$ lower increase in pension point value as of GDP in the long term. Furthermore, increasing the ratio of contributions will be limited to $22 \%$ from the current $18.9 \%$. This way of calculation slightly differs for the newly settled but the difference will disappear in the long term as salaries will harmonise. 
Allowances on social basis can be applied for if the old-age pension sources are not enough. These are to satisfy the 'primarily needs'. The amount of them is set by calculating the difference between individual needs and the income of the household. This 'average need' was 8724 EUR per person in 2012 for those who were entitled to this service.

There is voluntary private pension, as well which can be collected with the help of banks, insurance companies or investment funds. (It is termed as Riester pension). Riester pension is free from taxes and supported by the state. (The model is based on $4 \%$ contribution).

\section{Pension scheme in Poland}

In Poland the pension system is based on two pillars (NDC and DC system). Since 2014 the system has been voluntary, i.e. the employees can have a say in how their distributions (savings) are shared between the DC and NDC system.

Table 3. The key indicators of the pension system in Poland

\begin{tabular}{|l|l|}
\hline Indicator & \multicolumn{1}{c|}{ Value } \\
\hline average salary & 42360 PLN \\
\hline pension expenditures as of \% of GDP & $10.8 \%$ \\
\hline life expectancy at birth & 76.3 years \\
\hline life expectancy above 65 & 17.4 years \\
\hline percentage of the above-65 & $15.3 \%$ \\
\hline
\end{tabular}

Source: OECD (2015)

Conditions of entitlement to pensions in 2014 include 65 years and 3 months for men and 60 years 3 months for women. (For both men and women it is expected to rise to 67; for women by 2040 for men by 2020). Minimum pension can be received after paying in at least twenty one years' contributions (which is also expected to grow in the future).

In the pension system there are two fictitious accounts to set the amount of pensions: $16.6 \%$ of the salary is transferred to the individual fictitious account of the person in the form of a contribution. The fictitious interest rate is the equivalent of the growth rate of the salary but it should not be lower than the rate of inflation. (It has been in effect since 2000).

$2.9 \%$ of the salary is transferred to another sub-account as a contribution in the Social Security Fund /ZUS/). Indexing the contributions on the sub-accounts differs on the basis of the contributions on existing accounts. Moreover, it also takes heritage into account. The fictitious growth rate has been following the growth of nominal GDP in the past five years.

Employers can share $2.92 \%$ of their gross salary optimally in the DC system (OFE) (defined by contributions). From February 2014 51.5\% of the net assets of private pension funds have been transferred to the Institute of Social Security (ZUS). Moreover, those who opted to stay in private pension funds will gradually be transferred to the state system 10 years before their retirement. In addition to the changes in the operation of private pension funds the ways of calculating assets were established by these funds. The Social Insurance Institute is responsible for calculating and paying DC pensions as well as its combination with NDC.

When the person retires the accumulated fictitious capital is divided by ,g” value, which gives pension interest. This ,g" value is the mean life expectancy in the year of retirement. This process is similar to annulation. The life expectancy chart of the Central Statistical Office is used for calculating, ,g”.

The highest value of contributions and earnings is 2.5 times higher than the base average of the previous year. In 2014 the peak was 112380 PLN. Pension interests are regularly indexed and adjusted to inflation. Indexing covers the pension interests that were collected before indexing. 
Indexing comprises all sorts of interests. In certain years calculations may differ (such as in 2012). In 2013 the indexing rate of pensions was 104\%; in 2014 it was $101.6 \%$.

In the pay-as-you-go system there is minimum pension. The minimal value of old-age pension was 844.45 PLN in March 2014. In the new pension system the state budget must cover minimum pension and it is paid if the total compulsory old-age pension is lower than the minimum.

\section{Pension system in Sweden}

The Swedish pension system consists of a pay-as-you-go (PAYG) system, a defined benefit (DB) system and a defined contribution plan (DC). The operation of the pension system considers both contribution and allowances. The new Swedish pension system was accepted by the Parliament in 1994 and has been in effect since 1999. The new system is compulsory for those born after 1954 (to those born before 1937 the old system applies) while for those between the two are in transition between (Hutváger, 2013).

Conditions of entitlement to pensions include 61 years in the DC system. Guaranteed pensions are eligible at 65 and at least three years of living in Sweden is necessary. The maximum guaranteed pensions are available only after having been living there and if staying there for shorter, pensions are gradually reduced.

Table 4. The key indicators of the pension system in Sweden

\begin{tabular}{|l|l|}
\hline Indicator & Value \\
\hline average salary & 407974 SEK \\
\hline pension expenditures as of \% of GDP & $7.4 \%$ \\
\hline life expectancy at birth & 81.7 years \\
\hline life expectancy above 65 & 19.9 years \\
\hline percentage of the above-65 & $20.0 \%$ \\
\hline
\end{tabular}

Source: OECD (2015)

As a pension contribution all employees pay $7 \%$ while the employers $10.21 \%$ of their salary, respectively, which amounts to $17.21 \%$ of gross salary which means $18.5 \%$ as of the salary reduced by individual pension contribution $16 \%$ of which is transferred to individual accounts and divided evenly between four state pension funds (if pensions are paid from these funds), $2.5 \%$ will go to any of the investment funds eligible by the individual where it is invested till retirement and the real interest is accounted. Most of the contributions paid actually finance a defined pension system and the latter one a capital (so-called premium pension). The Swedish pension system is basically self-supporting. So as not to raise the current $16 \%$ contribution a balancing mechanism also works to offset certain demographic and economic effects to maintain long-term balance when future expenses are reduced to the same extent as the revenues decrease and in a favourable situation when revenues are on the rise, the opposite holds true.

The Swedish model also contains a minimum pension rule for those who do not have or just have low pensions. They can receive a maximised amount not from the state budget, but from the taxes.

\section{The pension system in Japan}

In Japan the pension system is similar to the Hungarian one (employer based pension system kosei nenkin). Due to the rapid demographic changes in the forthcoming decades government expenditures are expected to rise significantly. If the Consumption Tax covered the increased expenditure, without reforms tax would have to be raised to as high as $48 \%$ by 2080 (it was $5 \%$ in 2010). According to macroeconomic models increasing the income tax is not viable, either, 
as it would distort the economy and lead to the decrease in the labour supply in the end. Budget deficit can become unmanageable rapidly if covered by loans (Kitao, 2015a, Kitao, 2015b).

Table 5. The key indicators of the pension system in Japan

Source: $O E C D(2015)$

\begin{tabular}{|l|l|}
\hline indicator & \multicolumn{1}{c|}{ value } \\
\hline average salary & $4.88 \mathrm{mJPY}$ \\
\hline pension expenditures as of \% of GDP & $10.2 \%$ \\
\hline life expectancy at birth & 83.5 years \\
\hline life expectancy above 65 & 21.9 years \\
\hline percentage of the above-65 & $26.4 \%$ \\
\hline
\end{tabular}

In the case of Japan the results of the extremely important and unavoidable economic analyses are also presented. The model results show that in Japan such a budgetary policy is inevitable that reduces expenditure. A possible solution could be the introduction of the individual retirement system (IRA) when the employees could pay part of their salary on a pension account. This capital would be invested in production, which would enhance economic activity in the long term.

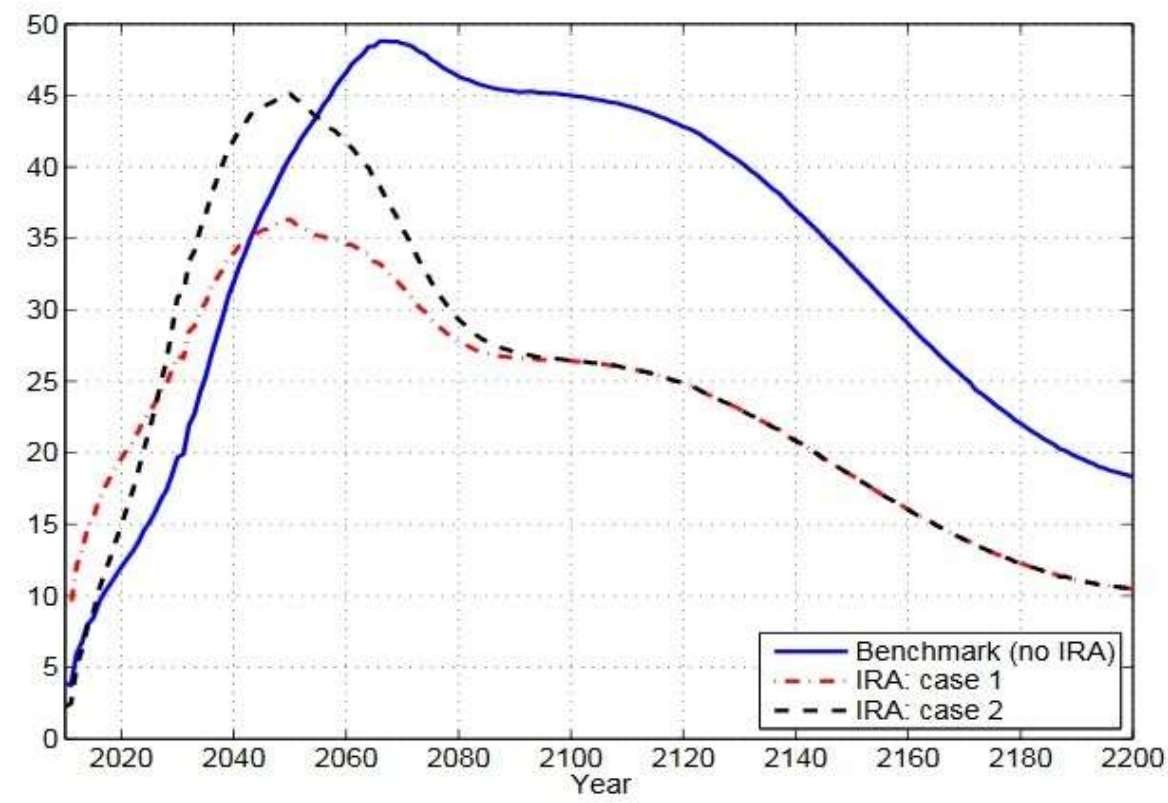

Consumption tax rate 2010-2200: models with and without IRA

\section{Figure 1 The amount of Consumption Tax with and without IRA (Temporary Case 1}

Source: Kitao (2015a) and 2)

The standard of model calculation is the future of keeping the present pension system (without IRA, benchmark). Starting from 2010 equilibrium is modelled during the period of transition. According to the figures Consumption Tax will steeply rise and reaches a peak of $49 \%$ in the 2060 's. Afterwards, it will decrease, though but for more than 40 years it will remain above $40 \%$ (!) till the beginning of 2130 's.

The introduction of the individual retirement system would result in the employees' saving and accumulating part of their income on a separate account to cover their expenses after retirement. The assets accumulated on their IRA accounts are invested, and this adds to production in the 
form of capital input. The model forecasts a 40 -year gradual transition and the pension system consists of two parts, i.e. the basic pension by the government and the payments from their own pension accounts. It is also predicted that gradually growing, $9 \%$ of the income will finally be accumulated in IRA. During these 40 years, however, personal income tax will be lowered by 9 percentage points. The budgetary equilibrium is projected to be reached by changing the consumption tax. There are several possible ways to transition of which two are analysed in details. The first case of transition is when the accumulation of pension contributions will be stopped immediately with the introduction of IRA; and in the second case of transition the pension contribution accumulation into the state pension fund is gradually phased out after the introduction of IRA. Figure 1 presents the results of the examination.

Calculations show that the consumption tax rates are higher the beginning of the transitory period in both IRA cases but finally taxes level off at a much lower rate than in the benchmark case without IRA. The introduction of the individual retirement system will have two profound changes. First, individuals feel more motivation to save for their retirement. Savings are channelled into production resulting in higher economic performance, higher wages and higher consumption. Second, the burdens of the state budget will be reduced, which can go along with the significant reduction of the consumption tax by the end of the transition.

\section{The pension system in Hungary}

At present most part of the government budget is taken up by pension expenses in the OECD countries. In Hungary it accounted for $10 \%$ of the GDP in 2015 and it is expected to grow in the forthcoming years. In an international comparison, it is strikingly high as the OECD average is $7.9 \%$. (OECD, 2015). The deviation is primarily due to the fact that our pension system is laid on one pillar exclusively, i.e. it is a system supervised by the state and financed by a defined pension system from one source for all the citizens. In contrast where pension reforms took place, the system was transformed into a three- or more-pillar pension system, i.e. not only state funds exist (the first pillar) but also employment-based pension (second pillar) and voluntary, private pension (third pillar), as well. (This was first termed by the 1994 publication of the World Bank and most OECD countries are actually using this division) Gál and Simonovits (2012) evaluates the annual interests of the Hungarian pension system. It is obvious that the increasing pensions mean heavier burden for the government so reforms are also inevitable in Hungary.

Table 6. The key indicators of the pension system in Hungary

\begin{tabular}{|l|l|}
\hline indicator & \multicolumn{1}{c|}{ value } \\
\hline average salary & $3.01 \mathrm{~m}$ HUF \\
\hline pension expenditures as of \% of GDP & $10.0 \%$ \\
\hline life expectancy at birth & 74.5 years \\
\hline life expectancy above 65 & 16.4 years \\
\hline percentage of the above-65 & $17.6 \%$ \\
\hline
\end{tabular}

Source: OECD (2015)

Hablicsekné (2014) presents the demographic analysis of the Hungarian pension system (based on life expectancy) and proves the necessity of reforms. The phenomenon of an ageing society is also a problem in Hungary and lack of pension funds can also be felt now. If we contrast the amount paid from an average salary to the Social Security Fund the missing amount per person per month is more than 40000 HUF.

In Hungary all payments into the private pension funds were suspended in Hungary between 1 November 2010 and 31 December 2011 and all the contributions were directed to the state pension fund. The members had to decide till 31 January 2011 whether to stay in the private 
pension fund or transfer to pay-as-you-go state pension fund. The private pension fund member has the opportunity to pay the individual account membership fee (but not contribution) to the private pension fund. So, the second pillar has already been demolished.

\section{Possible means of communication in the transformation of the pension systems}

Governments all over the world are paying more and more attention to properly inform and educate consumers so that they could make their financial decisions of improving complexity in a more well-established way. It especially holds true for pensions where pension funds and individual savings are getting more important as a consequence of the reforms.

Given the complexity of the topic the tools of 'relationship marketing' are worth employing in the campaign as it integrates acquiring and maintaining clients. The relationship with the client is due to last for long and it is not only about the transaction. As a consequence, the customer service, the advantages of quality, changes and new services are of high importance during the campaign in contrast with the tricks of advertising. (Little- Marandi, 2005)

The international literature presents several effective models and examples of communication that can assist pension reform campaigns. By experience, the success of the campaign depends on the fact if it can set timely, realistic and measurable objective for the contributors to have the maximum effect by being cost-effective, viable and innovative. Furthermore, communication should also be targeted and contain clear messages. (Atkinson et al, 2012)

As was expressed in the OECD's study on "Recommendation on good practices for financial education relating to private pensions" the main points of pension reforms have to be explained together with the ongoing necessity of self-care and individual savings as a consequence of demographical changes. In the meantime, transparency should be maintained to keep up trust and dedication to the new system.

Typically there are six factors that should be considered and continuously monitored during the campaign. They include

- What change is directed at - if the campaign explains the entire reform or just one/some part(s) of it.

- Target audience: the campaign calls for people in general or those concerned are in subgroups with specific, segmented communication.

- Who organises the campaign? It is usually performed by a governmental body but often it is passed down to a communication agency. In some cases the main organiser is the National Bank.

- Who are the most important stakeholders? Naturally, negotiations must take place with them on the most important objectives and implementation and possibly also about the form and content of coverages.

- The planned and real duration of the campaign.

- Who covers the costs? In most cases it is the government but sometimes it is the single stakeholders who can take some financial advantages from the changes that can finance.

It is essential to transfer the message to the target audience by using proper press and media. Without giving details about the drawbacks and strong points of the single opportunities the following channels can be mentioned: their own website; other internet surfaces; printed matter; media; billboard; surfaces of public transportation; public areas; social media; mobile phone advertisements.

As mentioned above, it is also important to take into account the properties of the target audience as we formulate the message. For the sake of our subject, it is therefore particularly important to see what financial consciousness and financial attitude the respondents have. 
'MAS' (Money Attitude Scale) developed by Yamauchi and Templer is the most frequently used measure in international literature to assess financial attitude. Regarding the fact that one of its modified versions is also used in our examination, the other characteristics of MAS are also presented in details. The research of Yamauchi and Templer is based primarily on the principles of Freud and neo-Freudian theories, which supposed three basic parts in the nature of financial attitude. They are security, retention and power prestige. The authors made $62 \mathrm{such}$ statements that reflect these 3 ranges and afterwards the items were assessed with the help of 300 volunteers by using a seven-grade Likert scale. Of the 62 statements finally a list of 29 items was selected by means of factor analysis. As a result, the following four items of the five categories below were isolated. (The fifth factor was added later by Roberts and Sepulveda.) Power-Prestige: according to the statements concerned money can be interpreted as a measure of power and success. The individuals who reach a high number of points in this factor regard money as an instrument of influencing/affecting others. Retention-Time: items belonging here are primarily focused on financial planning and taking good care of money. Those with a high number of points plan their future and continuously control their current financial situation. Mistrust: who reached a lot of points in this factor are insecure, suspicious and have doubts about themselves concerning money-related situations and the world of money. Anxiety: who have high scores of this factor regard money as a source of anxiety/nervousness. Quality: the statements belonging here focus on buying good quality products/services. The individuals who scored high here can be characterised by the saying: 'You get what you pay for'. According Mihaly et al (2017) the Hungarian young attribute a greater power-prestige role to the possession of money than their older counterparts but they also feel more insecure in the world of money. There is a slight difference between the responses of the two genders. According their results for men money rather means source of power and prestige and it is typical of them, although the difference is slight, that they make more savings/keep money than women. Women are more money-conscious 'bargain hunters' and they are more anxious about money and also, even to a slight extent, it is more typical of them to be uncertain and not sure in financial matters.

So the three most frequently referred challenges of communication campaigns are: 1 . indifference for the issue (especially for the young); 2 . the perceived or real complexity of the topic; 3. the low level of financial awareness. (Atkinson et al, 2012)

According the literature review and our experiences our main research hypotheses:

1. Young people are relative uninformed about pension systems;

2. The age influences the opinions (older people are worried more);

3. The gender influences the opinions (women are more worried).

\section{Results of the research}

\section{Qualitative achievements}

As mentioned in the methodological part, the sample is from the students of Szent István University, Faculty of Economic and Social Sciences (SZIU FESS). Interviews took place in Gödöllö and Budapest (at the Gödöllö and Budapest centre of education) typically in May 2016. Altogether 30 full-time and part-time students were interviewed (16 females and 14 males aged between 21 and 32) and the interviews lasted for 10-15 minutes.

As the respondents were the students of SZIU FESS (in logistics, business and management, marketing) we tried to keep the proportions typical of this multitude when selection was made. Interviews took place in calm environment, typically after or before lectures in a separate room (classroom or teachers' room). The possibility of recording their voice was rejected by most students at the beginning of the research so there also was a minute taker (a PhD student) apart from the interviewee. After an interview the interviewer and the minute taker discussed their 
notes. The willingness to response was very different per person (centre of education, BA/MSc, full time/part time) but general acceptance/rejection tendencies could not be detected, though.

The guide of the interview was similar to this.

- Topic objective of the interview, anonymousness, volunteering, confidential data

- What they know about the introduction of pension and the present Hungarian pension system

- If they heard/read something about the problems of Hungary related to pensions and/or internationally

- What future changes are expected

- How aware they are in finance, how they manage money

- From what sources they can imagine living in the future as a pensioner

- Saying thank you and good-bye

In general, the content of the interviews was very similar. With few exceptions most students are not adequately informed; the source of information is usually friend and relatives. The planned sequence of questions was hard to keep as the respondents changed to another subject: either the next or the previous one. No statistical difference could be detected on such sample size and segment (place of education level, time and gender) but it can be seen that correspondent students are more financially aware (as they are older and work in general).

According Yamauchi and Templer's three categories (Retention - Time; Mistrust; Anxiety) were separated. Some typical examples of the categories (what changes they expect, how they can live on, etc.) are quoting below:

Retention-Time (primarily focused on financial planning and taking good care of money): "Hopefully, from my savings in pension funds and other investments"; "I wish to cover the expenses of my old age retirement from my savings"; "Letting private enterprise and invest part of the income coming from there, and support my family from the other part"; "Private pension funds and the state will find out something"; "Presumably from my money earned and set aside abroad (I would like to grow old in Germany or Austria)".

Typical Mistrust answers (insecure; suspicious; doubts concerning money-related situations): "I do not have any ideas"; "We will not have pensions or savings, either as we do not have a decent salary"; "No more state pension fund existing"; "They say there will be no pensions"; "No more state pension fund existing"; "I guess when I grow old, I will not get pension". "Our generation will no longer have pension as there will not be producers".

Typical Anxiety answers (money as a source of anxiety/nervousness): "I just can hope it is not that bad as it is said"; "We will work till death if things go on like this"; "I guess we will not have much pension"; "The age limit will be pushed higher"; "We will not have pensions or savings, either as we do not have a decent salary". "No how, everybody says they are going to die under a bridge".

Interviews show that most of the participants deal with the issue, but they do not set aside their retirement. Many are sarcastically concerned with the subject (disillusioned, pessimistic), but at the same time they think they are able to create a calm old age.

\section{Results of the quantitative research}

Questionnaires were distributed among the students of Szent István University (Gödöllö). Requests and links (internet-based survey) were sent about how to fill in the questionnaire through the Neptun system to reach nearly 600 active students. In the introductory part of the 
questionnaire we informed the participants that it is part of a scientific project, anonymous and the responses are only used after summarisation. There were two calls to invite the students to fill in the questionnaire and they were finally closed on 30 June 2016.

The most important questions/issues of the questionnaire are the following (5-7 minutes' time is required to complete the full questionnaire).

- Are you worried about the amount of your would-be pension? (1-5 scale)

- What is the current pension age limit for men and women?

- How long do you think a man/woman lives in Hungary?

- What percentage of GDP is spent on pensions in Hungary?

- Do you have savings? If so, for what purpose?

- In addition to deductions at work, do you have any other savings/assets? If so, what type? Do you have (and if so, to what extent) does a loan bother you?

- What radio stations do you listen to and what TV channels do you typically watch? At what time of the day?

- What newspapers and internet portals do you usually read?

- Please, express your level of agreement with the statements above on a 7-grade scale. (There are 28 statements on financial awareness)

- Demographic questions (gender, age, qualification, residence, marital status, source of income).

Of the questionnaires returned 267 could reliably be assessed. The demographical breakdown of the sample is the following. Gender 168 female, 99 male; Highest qualification: secondary school $=147(\mathrm{BA})$, college $/ \mathrm{BA} / \mathrm{BSC}=90$, university/MA/MSC $=30$ (with two degrees). Finally the following groups were made according the age: $19-25=174,26-30=60$, above $30=33$.

This paper also resents statistically proven results. The methods of examination include variance analysis and in the case of categorical replies Chi-square test.

Questions: Are you worried about the amount of your would-be pension? (not at all=1, a bit=2, so-so $=3$, very $=4$, to a great extent $=5$ ).

Table 7. Worry about the pension according to age

\begin{tabular}{|l|l|}
\hline Age group & Average \\
\hline $19-25$ & 3.28 \\
\hline $26-30$ & 3.05 \\
\hline above 30 & 4.18 \\
\hline total & 3.34 \\
\hline
\end{tabular}

Source: author's own experiment

It can be seen (and understood) that the third, oldest age group regards this question as the most important, Sig=0,026). We must note, however, that when analysing the two younger age groups the average difference (between 3.28 and 3.05) is not significant (Sig=0,451)

Table 8. Worry about the pension according to $\mathrm{g}$ ender

Source: authors' own compilation

\begin{tabular}{|l|l|}
\hline Gender & Average \\
\hline female & 3.54 \\
\hline male & 3.00 \\
\hline entire sample & 3.34 \\
\hline
\end{tabular}


Women significantly appreciate the issue. ( $\mathrm{Sig}=0,026)$.

There is no statistical difference of demographical variables in the following questions.

Do you have savings? yes/no entire sample $=55.1 \%$

Do you have pension savings? yes/no entire sample $=9 \%$

Have you ever been burdened by credits and loans? yes $/$ no entire sample $=15.7 \%$

Question: Evaluating statements on financial items (MAS) on a 7-degree scale (1=I can hardy agree, $7=$ I entirely agree.)

Statistically proven significant differences are in above items.

Table 9. Financial awareness-gender

\begin{tabular}{|l|l|l|l|l|}
\hline statement & female & male & total & Sig = \\
\hline People say I overemphasize money & 2.41 & 3.27 & 2.73 & 0.019 \\
\hline I use money to influence others & 1.38 & 2.24 & 1.70 & 0.004 \\
\hline Sometimes I boast how much money I made & 1.73 & 2.39 & 1.98 & 0.033 \\
\hline $\begin{array}{l}\text { When I bought something, it disturbes me afterwards } \\
\text { how much it cost }\end{array}$ & 3.89 & 2.79 & 3.48 & 0.012 \\
\hline I bargain hunt regularly & 3.93 & 2.61 & 3.44 & 0.002 \\
\hline
\end{tabular}

Source authors'own editing

Table 10. Financial awareness-age

\begin{tabular}{|l|l|l|l|l|l|}
\hline Statement & $19-25$ & $26-30$ & $30+$ & total & Sig = \\
\hline $\begin{array}{l}\text { I am overwhelmed by problems when it comes } \\
\text { to money }\end{array}$ & 3.09 & 4.20 & 4.36 & 3.49 & 0.018 \\
\hline $\begin{array}{l}\text { I am typically nervous if I do not have enough } \\
\text { money }\end{array}$ & 4.03 & 4.00 & 6.09 & 4.28 & 0.030 \\
\hline
\end{tabular}

Source: authors 'own editing

1. The firs hypothesis ("Young people are relative uninformed about pension systems") was not justified, as the measurement equipment was not well for the data collection. The differences between gender and age have been proved, according the second and third hypothesis. (2. The age influences the opinions - older people are worried more; 3 . The gender influences the opinions - women are more worried). In our measurement, the younger do not worry about the pension problems so much and show less anxiety in financial matters. Male are worry less about possible pension retirement and financial procedures and more "power and prestige oriented" ("People say I overemphasize money"; "I use money to influence others"; "Sometimes I boast how much money I made") while women show higher scores in "anxiety" and "quality" dimensions of MAS. The earlier mentioned Mihaly et al (2017) research achievements were close similar about money attitude, which means that it is worth keeping in mind the gender and age differences when we launch a campaign on pension savings.

\section{Summary}

A great number of OECD and EU studies show that for most countries it is indispensable to transform the pension scheme in the long term. For this, the entire population but especially the young must be prepared. Lack of pension is a challenge for all the strata of society but if savings are started on time, it does not mean an unbearable burden. Our research clearly shows that in addition to the inevitable economic-like macroeconomic analyses there is a need for thorough (representative) researches that point out the attitudes and competencies to pension by the different layers of society and explore the communication tools of persuasion. 


\section{References}

1. Atkinson, A et. al. (2012): Lessons from National Pension Communication Campaigns, OECD Working Papers on Finance, Insurance and Private Pensions, No. 18, OECD Publishing. DOI: http://dx.doi.org/10.1787/5k98xwz5z09v-en

2. Gál R. I., Simonovits A.(2012): A magyar nyugdíjrendszer éves hozamrátái. Közgazdasági Szemle. 59 (9) 963-987.

3. Hablicsekné Richter M. (2014): A nyugdíjban, nyugdíjszerü ellátásban részesülők halandósága a főbb ellátástípusok szerint. PhD értekezés. SZIE Gazdálkodás- és Szervezéstudományok Doktori Iskola. Gödöllő.

4. Hutváger I. (2013): A svéd és a német nyugdíjrendszer összehasonlítása. ELTE TTK (szakdolgozat). Budapest.

5. Kitao,S. (2015a): Pension reform and individual retirement accounts in Japan. Journal of The Japanese and Internaztonal Economies. 38 (2015) 111-126. DOI: https://doi.org/10.1016/j.jjie.2015.06.002

6. Kitao, S. (2015b): Fiscal cost of demographic transition in Japan. Journal of Economic Dynamics and Control. 54 (2015) 37-58. DOI: https://doi.org/10.1016/j.jedc.2015.02.015

7. Little, E. - Marandi, E., (2005): Kapcsolati marketing. Akadémia Kiadó, Budapest. (Original: „Relationship Marketing Management”, 2003)

8. Mihály, N. - Kovács, I. É. - Madarász, I. - Mészáros, A. (2017) Correlations Between Attitude To Money And Demographic Variables On A Sample Of University Students. Regionalnaja Ekonomika: Jug Rossii/Regional Economy: The South Of Russia 3:(17) 55-72. DOI: https://doi.org/10.15688/re.volsu.2017.3.6

9. OECD (2015): Pensions at a Glance 2015: OECD and G20 indicators, OECD Publishing. Paris. DOI: http://dx.doi.org/10.1787/pension_glance-2015-en

10. Recommendation on Good Practices for Financial Education Relating to Private Pensions. www.oecd.org/daf/pensions. (06.01.2016)

11. Yamauchi K.T. - Templer D.L., (1982): The development of money attitude scale. Journal of Personality Assessment. 46 (May), 522-528. DOI: https://doi.org/10.1207/s15327752jpa4605_14 